\title{
Farmers' management of rice varietal diversity in the mid-hills of Nepal: implications for on-farm conservation and crop improvement
}

Article

Published Version

Rana, R. B., Garforth, C. and Sthapit, B. R. (2009) Farmers' management of rice varietal diversity in the mid-hills of Nepal: implications for on-farm conservation and crop improvement. Plant Genetic Resource: Characterization and Utilization, 7 (1). pp. 50-62. ISSN 1479-263X doi: https://doi.org/10.1017/S1479262108048259 Available at https://centaur.reading.ac.uk/24796/

It is advisable to refer to the publisher's version if you intend to cite from the work. See Guidance on citing.

To link to this article DOI: http://dx.doi.org/10.1017/S1479262108048259

Publisher: Cambridge University Press

All outputs in CentAUR are protected by Intellectual Property Rights law, including copyright law. Copyright and IPR is retained by the creators or other copyright holders. Terms and conditions for use of this material are defined in the End User Agreement. 


\section{www.reading.ac.uk/centaur}

\section{CentAUR}

Central Archive at the University of Reading

Reading's research outputs online 


\title{
Farmers' management of rice varietal diversity in the mid-hills of Nepal: implications for on-farm conservation and crop improvement
}

\author{
R. B. Rana ${ }^{1}$, C. J. Garforth ${ }^{2}$ and B. R. Sthapit ${ }^{3 *}$ \\ ${ }^{1}$ Local Initiatives for Biodiversity, Research and Development (LI-BIRD), PO Box 324, \\ Pokhara, Nepal, ${ }^{2}$ University of Reading, PO Box 237, Reading RG6 6AR, UK and \\ ${ }^{3}$ Bioversity International, 3/10 Dharmashila Buddha Marg, Nadipur Patan, Pokhara, Nepal
}

Received 7 April 2008; Accepted 20 July 2008 - First published online 6 August 2008

\begin{abstract}
Season-long monitoring of on-farm rice (Oryza sativa, L.) plots in Nepal explored farmers' decision-making process on the deployment of varieties to agroecosystems, application of production inputs to varieties, agronomic practices and relationship between economic return and area planted per variety. Farmers deploy varieties [landraces (LRs) and modern varieties (MVs)] to agroecosystems based on their understanding of characteristics of varieties and agroecosystems, and the interaction between them. In marginal growing conditions, LRs can compete with MVs. Within an agroecosystem, economic return and area planted to varieties have positive relationship, but this is not so between agroecosystems. LRs are very diverse on agronomic and economic traits; therefore, they cannot be rejected a priori as inferior materials without proper evaluation. LRs have to be evaluated for useful traits and utilized in breeding programmes to generate farmer-preferred materials for marginal environments and for their conservation on-farm.
\end{abstract}

Keywords: crop improvement; farmer's decision making; intensive data plots; landrace; on-farm conservation; rice; Nepal

\section{Introduction}

Landraces (LRs), often called traditional or local varieties, contain the genetic diversity used for the generation of new and improved crop varieties, and are the basis for scientific plant breeding (Harlan, 1975; Zeven, 1998; Bellon, 2008). They generally exhibit high degrees of local adaptation, with particular traits that are valuable to the communities in which they are cultivated and managed. The global on-farm conservation study of the 27 crop species from five continents showed that considerable crop genetic diversity continues to be maintained onfarm, in the form of LRs ( Jarvis et al., 2008). Because of their

*Corresponding author. E-mail: b.sthapit@cgiar.org genetic diversity and local adaptation, LRs are the focus of most agricultural biodiversity conservation efforts (Brush, 1995; Smale et al., 2004; Horneburg and Becker, 2008). Hodgkin et al. (1993) stated that the most important feature of LRs is that human intervention is needed to create and maintain them. Environmental, biological, socio-cultural, economic and policy factors influence a farmer's decision to select and replace or maintain a particular variety at any given time (Jarvis et al., 2000). In the process of planting, managing and harvesting and selecting seeds, farmers make crucial decisions that affect genetic diversity of the crop populations over time (Cleveland et al., 2000; Jarvis and Hodgkin, 2000).

Conservation-oriented literature suggests that multiple farmer concerns (e.g. yield, risk and quality), specific food culture (Carpenter, 2005; Sthapit et al., 2008), environmental 
heterogeneity and missing market links contribute to the persistence of LRs on-farm (Brush and Meng, 1998; Perales et al., 1998). LRs represent one of the major economically valuable components of global biodiversity with immediate use by numerous subsistence-oriented farmers (Wood and Lenne, 1997). Therefore, LRs can have private value for individual farmers and, thus, are maintained in many places in the world (Smale et al., 2004). However, often breeders view the persistence of LRs as a sign of backwardness and LRs that need to be replaced by 'modern varieties (MVs)' (Witcombe et al., 2005).

Among other reasons, because formal breeders are not generating materials 'tuned with the agroecosystems', farmers continue to rely on LRs for their needs (Frankel et al., 1995; Tripp et al., 1997). However, others argue that resource-poor farmers in marginal environments have benefited less from MVs because they do not have access to suitable MVs and not because there are no suitable MVs (Witcombe et al., 1996; Mulatu and Belete, 2001; Virk and Witcombe, 2006). The genetic diversity of LRs is vital to such farmers' ability to use agroecosystems that are marginal for rice production to help sustain their livelihoods. Traits in LRs that have been suggested as pro-poor traits (defined as the heritable trait of traditional variety that enhances productivity, adaptability and stability of crops important to the poor by robust genetic protection of crops from abiotic and disease stresses) include adaptation to marginal growing environments (drought tolerant, shade tolerant, cold tolerant, disease and pest tolerant, production under low-fertility regime and production under submerged or deep water; Science Council Secretariat, 2005). A pro-poor trait has three characteristics: (1) it can be used by poor farmers; (2) it does not require costly external inputs; and (3) it is relatively simple to use and maintain.

In this study, we set out to demonstrate that rice LRs are diverse genetic resources containing pro-poor traits especially suited for marginal environments. Under adverse conditions, LRs can still outyield recommended cultivars (Frankel et al., 1995), but systematic studies on farmers' existing situation are seldom characterized to assess the value of LRs for multiple uses.

Season-long monitoring of rice (Oryza sativa L.) varieties on-farm at plot level was used to generate information on farmers' decision making in relation to plant genetic resources management on-farm. Specifically, this study was designed to test the following hypotheses:

(1) LRs in certain niche environments are as competitive as MVs.

(2) Costs and returns differ greatly among LRs and between LRs and MVs.
(3) Farmers' preferential management of varieties depends on the economic return they generate.

(4) Farmers' decision on the population size (measured by the area planted) of varieties depends on the economic returns they generate.

\section{Materials and methods}

\section{Study site}

The study site - Begnas village in Kaski district of Nepal - lies in the mid-hill region with elevation ranging from 600 to 1400 masl. This site represents mainly low hill, river basins to middle hills physiographic region from eastern to western Nepal. Cereals are major contributors of food security followed by offfarm income and products of mixed agriculture including some livestock. It receives an annual rainfall of about $1300 \mathrm{~mm}$. The farming system is predominantly subsistence oriented with rice-based cropping pattern in khet land (bunded and irrigated/rainfed land where puddle rice is grown) and maize-based cropping pattern in bari land (unbunded rainfed upland). The village is representative of mid-hill conditions in Nepal with medium level of intervention from formal research and extension systems and modestly developed road and market networks. Mid-hills, the transition zone between plains and high hills, harbour most of the varietal diversity of rice.

\section{Data collection and analysis}

Intensive data plots technique (Hobbs et al., 1996) was used to understand the real situation of on-farm crop diversity management. Farmers, through focus group discussion, identified four distinct agroecosystems for rice: upland, rainfed lowland, irrigated and marshy land. This classification closely matches the one identified by Khush (1984), except for marshy land which he described as flood-prone agroecosystem. In this study, upland cultivation is ignored because it occupies only about 3\% of total rice area and continues to decline in the village. From each of the three other agroecosystems, the most dominant landrace (LR) and MV in terms of area planted were selected for the study. Farmers identified the following varieties: Mansara (LR) in rainfed agroecosystem; Thulo Gurdi (LR) and Ekle (LR) in irrigated agroecosystem; and Jetho Budho (LR) and Mansuli (MV) in marshy agroecosystem (Tables 1 and 2). Only one MV was found to be widely grown by sufficient number (15\% of sampled households (HHs)) of sample farmers. Except for the last one, others 

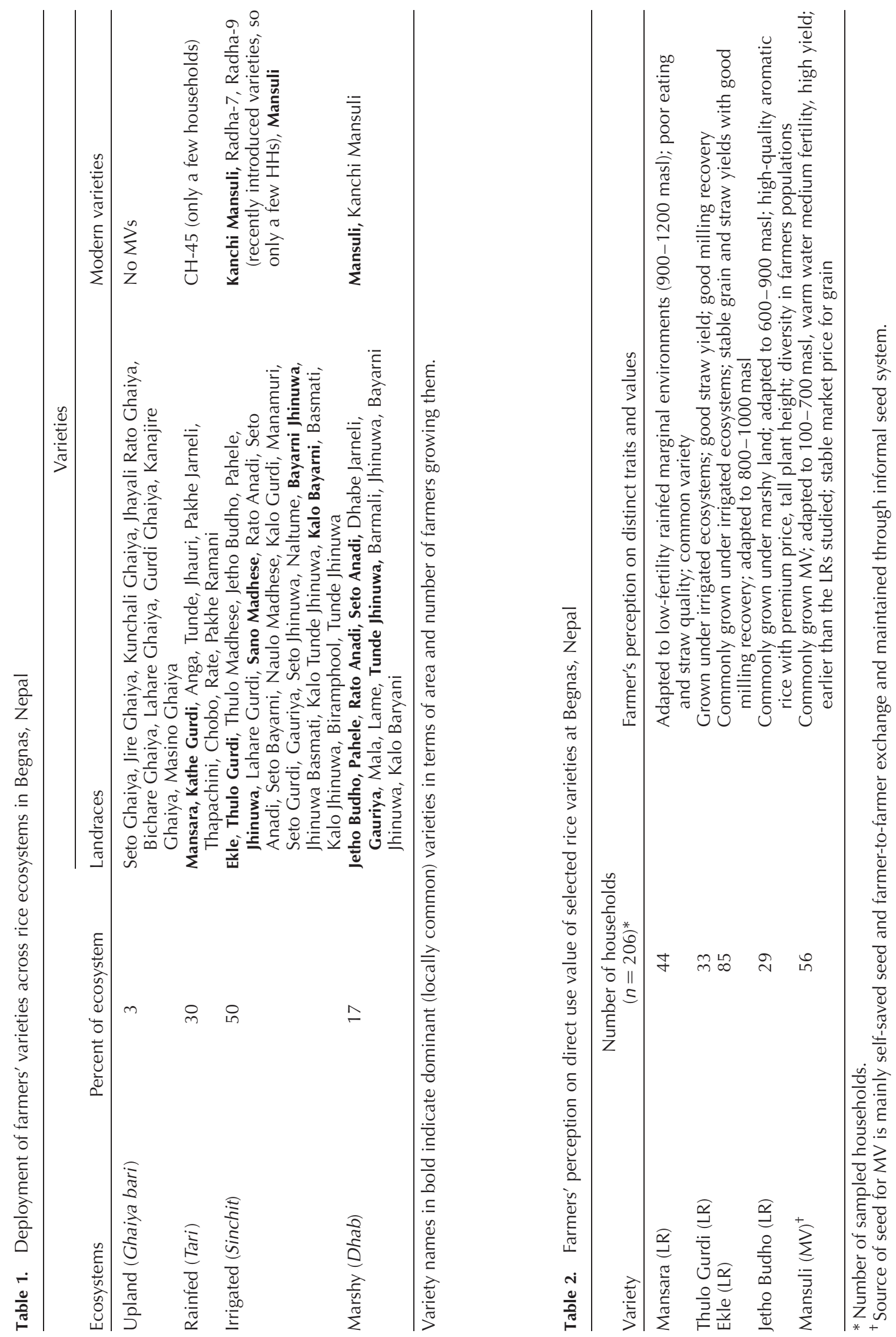
are LRs. Farmers also identified HHs growing these varieties for intensive monitoring at plot level.

Many farmers tend to give names to LRs based on a morphological trait (Harlan, 1975) and different LRs are understood to differ in adaptation to land types, farming systems, phenology, post-harvest characteristics, tolerance to diseases and pests, abiotic stresses, yield and yield components, nutritive value and other uses, many of which are part of farmers' descriptors (Sadiki et al., 2007). Selected LRs contain genetically identifiable populations and farmers are consistent in naming and describing the cultivars (Bajracharya, 2003), but a poor correlation between LRs names and their traits has been reported in some literature (Sadiki et al., 2001).

Hobbs et al. (1996) used the technique of intensive data plots (IDPs), which involved participatory recording and analysis of on-farm activities in a rice-wheat system, to have an insight into farmers' behaviour and decisionmaking process (Rana and Sthapit, 2006). The study was conducted on existing farmer plots and with a few common LRs only because the study's aim was to understand whether on-farm management practices and economic return of each LRs are same or different. In the present study, IDP monitoring was conducted in JulyNovember 2002. A total of 90 farmers participated in the study. While selecting participant farmers in rainfed and irrigated agroecosystems $(n=50)$, those growing all the three LRs namely Mansara, Ekle and Thulo Gurdi were identified to observe intra-household allocation of resources for these LRs. For marshy agroecosystem, 40 farmers were selected, of which 36 planted Jetho Budho and 34 planted Mansuli. As far as possible, similar fertility and moisture gradient were maintained between varieties by selecting Ekle and Thulo Gurdi for irrigated plots, and Jetho Budho and Mansuli for marshy conditions, side by side. Farmers and researchers jointly identified study plots in farmer's fields for these varieties. Researchers paid fortnightly visits to participant farmers and their plots to monitor and record farmers' management of LRs and MV (Mansuli) over the rice-growing season right from field preparation to harvesting and storage. Gender roles in rice production and contribution of family and hired labour were recorded, along with costs of inputs - seed, farmyard manure (FYM), chemical fertilizers and pesticides. Two random crop cuts of $2 / \mathrm{m}^{2}$ each from individual plots were used to record grain and straw yields. The yield (ton/ha) of rice was adjusted to $12 \%$ moisture, and for straw the local unit called bhari (bundle) was used for estimating the economic return. Collected data were utilized to calculate the economic return for LRs and MVs, and to relate the output to area planted to these varieties.

The data were entered onto an Excel spreadsheet and analyzed using SPSS for Windows. For comparison among test entries, descriptive statistics such as mean, standard error of mean (SE) and coefficient of variation (CV) were generated for individual varieties. T-Test was performed to measure the statistical differences on grain and straw yields of Mansara vs. Thulo Gurdi, Mansara vs. Ekle, Ekle vs. Thulo Gurdi and Jetho Budho vs. Mansuli. Because of the specific adaptation of Jetho Budho and Mansuli, they do not compete with the former three LRs for space; hence, comparison between ecosystems was not done. One way analysis of variance (ANOVA) was performed on varieties for parameters such as seed rate, manure and chemical fertilizer application and selected agronomic traits.

\section{Cost-benefit analysis of producing different rice varieties}

Costs and benefits of producing different rice varieties were analyzed and compared to farmers' decision on area planted to these varieties. Detailed monitoring was crucial to apportion costs appropriately into different operations used to grow, harvest and store selected varieties. While calculating the cost of production, among other factors, the contribution made by $\mathrm{HH}$ labour force, costs of FYM and seeds have been included based on prevalent prices of these commodities in the village. Monetary value generated was calculated using grain and straw yields multiplied by prevailing price in the village.

\section{Results}

\section{Farmers' management of rice varieties}

\section{Seed management}

Seed is always selected from 'best plots' and farmers employ a variety of seed selection techniques depending on the specific purpose of the variety being grown and scale of operation. LRs with religious, cultural and social values receive better care while selecting seed to avoid seed mixture, which would render the grain unsuitable for religious ceremonies. Farmers rely on both formal sources and informal networks to acquire new varieties and quality seeds. Three distinct components of farmers' management of diversity on-farm were identified. First is the 'variety choice' - the process by which a farmer decides which varieties to plant in what proportion of the farm. Second refers to 'seed selection and management' - the process of selecting seeds/planting materials, and handling the seed cycle from planting to harvest. The third is 'seed flow' - the process by which a farmer acquires physical units of seed for planting that 
could be from their own selected seed saved from the previous season, exchange or purchase, or a combination of sources. This paper focuses on the latter two components of farmers' management of rice varietal diversity on-farm as the maintenance of landrace cannot be done without continued human interventions. Seed selection was mainly done to maintain the productivity of a given variety and preferred traits.

\section{Rice nursery}

Farmers at Begnas practised dry bed nursery for raising rice seedlings. The amount of seed used ranged from 35 to $78 \mathrm{~kg} / \mathrm{ha}$ depending on the variety, with $50 \mathrm{~kg} / \mathrm{ha}$ as standard for MVs (Gorrez and Chaurasia, 1997). A significant difference $(P<0.01)$ was observed in the amount of seed used between varieties (Table 3 ). Farmers primarily relied on their own saved seeds for planting followed by exchange with neighbours and relatives. Some farmers (24\% HHs) also acquired MV from outside sources, indicating farmers' access to quality seeds of MVs from formal sources including the market. For LRs, no such provisions exist because the government research and extension system promotes only formally released varieties through their programmes (Paudel et al., 2003).

\section{Manuring in the rice nurseries and in the main rice fields}

Farmers applied FYM in the rice nurseries as well as in the main rice fields (Table 3). On average, farmers applied slightly higher amount of manure on Mansara plots (8.7 $\pm 1.1 \mathrm{ton} / \mathrm{ha})$ compared with Thulo Gurdi plots $(7.7 \pm 0.8 \mathrm{ton} / \mathrm{ha})$, though the difference was not statistically significant $(P>0.05)$. Farmers applied more manure for Mansuli (12.4 \pm 1.4 ton/ha) and Jetho Budho $(12.6 \pm 1.8 \mathrm{ton} / \mathrm{ha})$ compared with the rest of the LRs. The difference in the amount of manure applied to varieties was significant $(P<0.001)$, but the difference was not significant $(P>0.27)$ for varieties grown in the same agroecosystem.

\section{Land preparation and rice transplanting}

Under land preparation, three distinct activities - ploughing, slicing terrace risers and repairing bunds, and puddling - were performed at different times. Slicing terrace risers, clearing weeds and repairing bunds to hold water in the rice field were done followed by puddling before rice transplanting on the same day. Ekle was transplanted earliest followed by Jetho Budho, Mansuli and Thulo Gurdi that were transplanted later. Application of chemical fertilizer - diammonium phosphate - as basal dose at the time of rice transplanting was practised extensively for Mansuli (71\%) and Jetho Budho (72\%), but not for other LRs.

\section{Weeding and top dressing}

First weeding was conducted at 5-7 weeks after rice transplanting. During weeding, farmers top dress rice crops with urea. Application of urea ranged from $25 \pm 2$ to $56 \pm 6 \mathrm{~kg} / \mathrm{ha}$ for different varieties. Top dressing with urea is a common practice for all varieties; Jetho Budho and Mansuli (MV) receive higher amount of urea as top dressing. The difference in the amount of urea applied to MV (Mansuli) was statistically higher $(P<0.05)$ compared with LRs.

\section{Harvesting of rice and yields of grain and straw}

Among the varieties studied, Mansuli was harvested earliest (within October) and Jetho Budho matures about a month later. Though Mansara was generally planted late, it was harvested by the first week of November as it matures early. Ekle's harvesting period extends into the second week of November. Harvested plants were thinly spread on the field for sun drying for $2-3 \mathrm{~d}$ to reduce the moisture content of grain and straw to prevent mould and fungus growth.

The average grain yields estimated by crop-cuts method ranged from 2.2 to 5.1 ton/ha, with lowest yield recorded for Mansara and the highest for modern variety Mansuli (Table 3). The other three LRs yielded between 3 and 3.5 ton/ha. Analysis of grain yield for varieties within the agroecosystem indicated that there was no statistically significant difference $(P>0.05)$ in yield for Thulo Gurdi and Ekle, but the difference was significant $(P<0.05)$ for Jetho Budho and Mansuli. The straw yields for varieties ranged from 7 to 22 ton/ha, and the differences in straw yield were statistically significant $(P<0.001$; Table 3).

\section{Stacking, threshing and storage of grains and straw} The sun-dried plants were bundled and stacked at one place within a rice field. Threshing usually occurs by beating a bundle of rice against a hard surface. The threshing period may extend to more than one month for Jetho Budho and Mansuli, whereas for Mansara, Thulo Gurdi and Ekle threshing happens immediately after stacking. Threshing is followed by winnowing of grains, and then filling them into bags to transport to home. Straw is made into bundles that are carried for stacking in 'tauwa' (stack of paddy straw) at the homestead. Straw is valued as livestock feed in the hills and is used throughout the year.

\section{Labour, gender and rice production}

The detailed recording of different roles of female and male farmers in rice variety production was done fortnightly. The traditional division of labour is based 


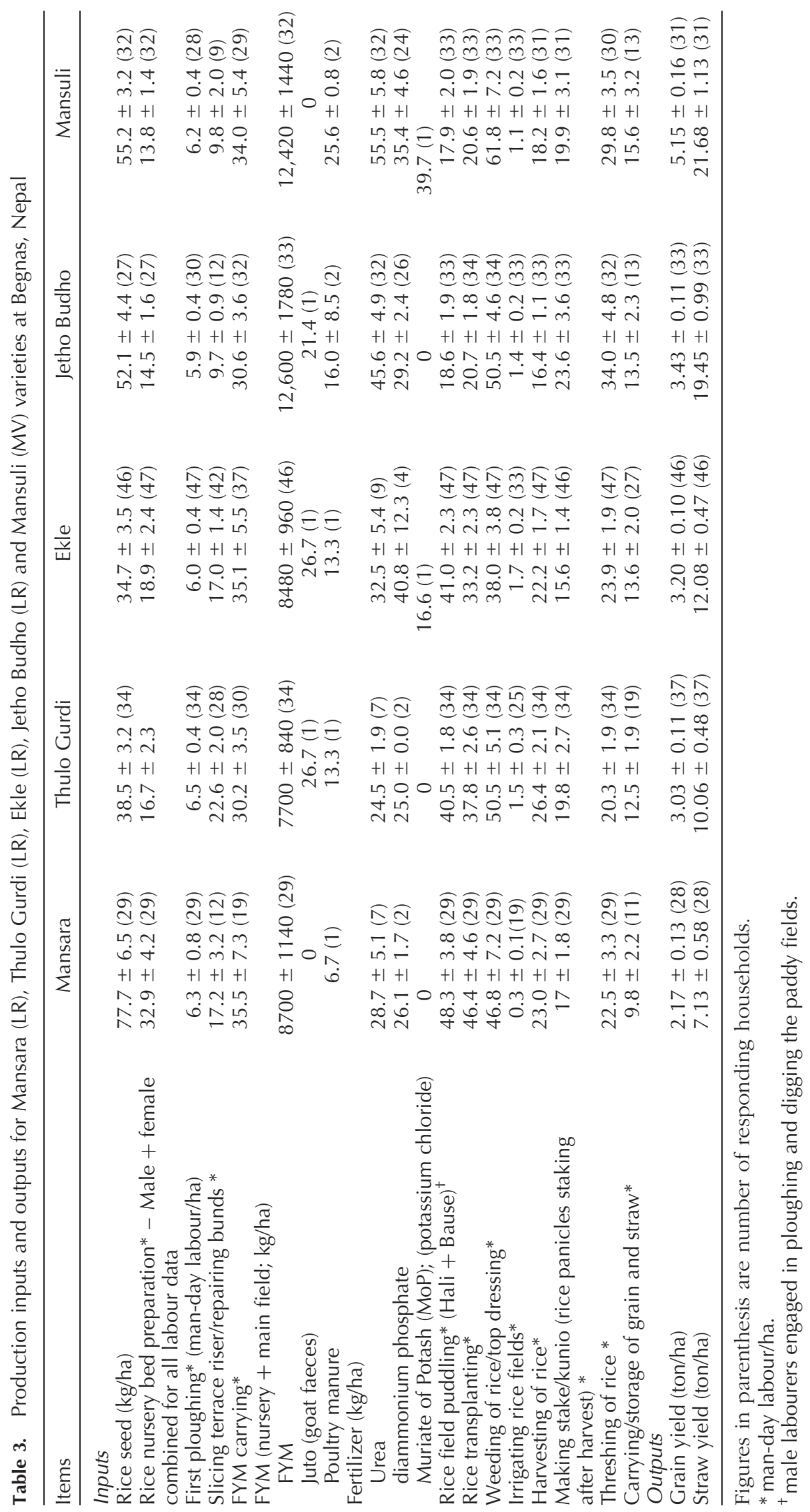


mainly on physical strength required to accomplish individual tasks. For instance, transplanting is the exclusive domain of women and so is FYM carrying, whereas ploughing, slicing terrace riser, repairing bunds and puddling are considered in the male domain. Nevertheless, in 8 out of 12 activities recorded, rice production required the expertise and strengths of both female and male members to complete the task. Differential wage rates have been fixed according to community's perception on the need of physical strength for performing specific activity. Activities such as ploughing, puddling, repairing bunds and threshing require more physical strength and accordingly paid a higher wage (Rs 150/person/day). Rest of the activities (nursery preparation, manure carrying, transplanting, weeding and harvesting) are considered to require less physical strength and hence are paid a lower wage (Rs 60/person/day). However, there is no discrimination in wage rates when female and male perform the same activities such as manure carrying and harvesting.

Labour requirement for Mansara surpassed all other varieties. While considering the mean figures for labour requirements, Mansara production for 1 ha required 306 person days as against 239 for Jetho Budho. For other varieties, the labour requirement ranged between 249 and 285 person days. Mansara had higher labour requirement because it was cultivated on small terraces with heterogeneous environments under rainfed conditions that make operations such as manuring, transplanting and weeding more difficult.

Household labour was relied on for the majority of activities in rice production. In addition, different kinds of labour arrangements such as hiring and reciprocal labour exchange systems called parma are practised for specific activities that have high labour needs such as transplanting, threshing, weeding and harvesting. Labour from within HHs performed activities such as irrigation of rice field, carrying FYM, top dressing and storage of grain. Both female and male members were equally involved in hiring and parma systems.

\section{Cost-benefit analysis of producing different rice varieties}

Table 4 shows the production cost for different varieties, which ranged from Rs 35,926 to 40,556/ha (78 rupees $=1$ US dollar at the time of data recording), with least cost of production for Mansuli and the highest for Thulo Gurdi. Labour was the dominant cost, ranging from 68.0 to $81.2 \%$ of the total, least being for Jetho Budho and the highest for Mansara. Rice field preparation at the time of transplanting accounted for $8-19 \%$ of the total cost. Weeding of rice field also added considerably to the cost $(7-14 \%)$. FYM cost ranged from 13 to $26 \%$ of the total cost. Farmers' differential management of agroecosystems was evident from the amount of manure applied to different varieties. Contribution of purchased inputs such as fertilizer $(2-5 \%)$ and seeds $(2-4 \%)$ in the cost portfolio was minimal.

Gross returns generated for different varieties ranged from Rs 39,436 to 93,430/ha. Two scenarios for calculating net return have been presented: (1) net return on grain and straw and (2) net return on grain only. When the grain and straw yields were converted into monetary value, Mansuli (MV) was the most profitable variety followed by fine-quality Jetho Budho. However, straw of Jetho Budho is most valued for animal forage and preferred for straw mat making. Both of them are from the same agroecosystem - marshy land. The straw value of Mansuli is not valued highly by farmers for forage because of its high silicon content and poor palatability. In irrigated production system, Ekle was 34\% more profitable than Thulo Gurdi. In rainfed agroecosystem, Mansara could barely break even to cover the cost of production. When the value of straw was not considered in the calculation of net return, Jetho Budho was more profitable than Mansuli, but for irrigated LRs the equation remained unchanged, and Mansara registered a negative figure.

\section{Relationship between economic return and area coverage by different rice varieties}

The economic return and area coverage under selected varieties for specific agroecosystems are presented in Table 4. Results indicate that there is a positive relationship between total economic return and area coverage for varieties within a given agroecosystem, i.e. higher the economic return larger the area under the variety. For example, Ekle with higher economic return per unit area occupies larger area than Thulo Gurdi. Similarly, Mansuli with higher economic return is grown in larger area than Jetho Budho. Farmers' decision on area allotment is to some extent governed by demand of the grains in local market and prevailing price. For instance, Jetho Budho (aromatic fine rice with good eating quality - softness and aroma of cooked rice) has good demand and fetches good price, hence it is marketed; whereas, other varieties are used for home consumption. However, not all farmers are comfortable selling high-value aromatic rice and buying other varieties of rice for home consumption because farmers are not fully integrated with the market economy. Farmers expressed that buying rice for home consumption is still deemed unfavourably in the community. This explains a large difference in area between Mansuli and Jetho Budho though the economic margin is not so great. There is 


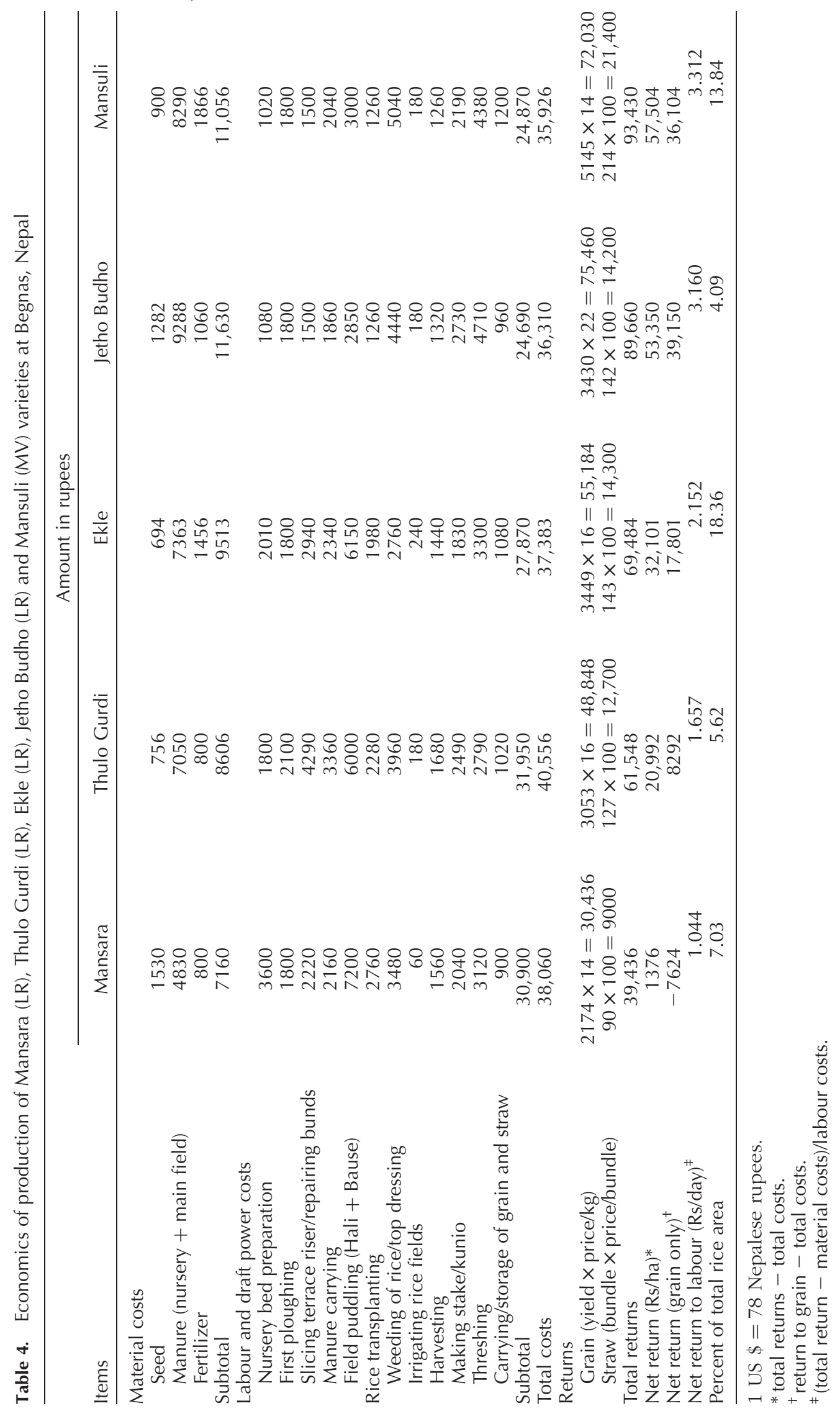


no relationship between economic return and area coverage for varieties grown in different agroecosystems because varieties compete for areas and other resources within the agroecosystem.

\section{Discussion}

Hypothesis 1: Landraces in certain niche environment are as competitive as MVs.

Mansara is traditionally grown in poor and marginal conditions, so farmers added a little more manure. This shows that farmers are considering the relative production potential of the land in their decision making. Despite very low return from Mansara, farmers are forced to grow this landrace in rainfed agroecosystem because no other landrace or MV does better in this target environment. The variety is the only available option to farmers in such poor environments. Results from the study support the hypothesis that in certain agroecosystems LRs are as competitive as MVs in production or economic return, whereas in extreme environments (upland and rainfed agroecosystems) they are the primary options available to farmers (Table 1) as the number of released cultivars is meagre. It is well recognized that resource-poor farmers in marginal areas have benefited less from formal breeding programme (Witcombe et al., 1996; Atlin et al., 2001). Absence of other competing varieties illustrates lack of options in that agroecosystem and indicates the inability of the formal research system to breed varieties suitable to that environment. Some researchers have noted that in certain local circumstances or micro-niches, especially in stress environment, LRs have been found to be competitive or superior to MVs in yield or total economic return (Byerlee, 1996; Sthapit et al., 1996; Perales et al., 1998; Ceccarelli, 2000) because plant breeding for all situations will be an expensive approach. Table 4 illustrates that farmers are maintaining Mansara rice variety despite poor economic return because of its better genetic correlation with the target production environment. From a conservation point of view, Mansara landrace is valued for its adaptive trait in a marginal environment and has useful pro-poor traits for crop improvement (Gyawali et al., 2005a). However, there is the risk of losing this useful genetic diversity if an alternative becomes available. The on-farm conservation programme needs to improve productivity and quality of Mansara by retaining co-adaptive complexes of the landrace population so that Mansara variety remains competitive in marginal ecosystems. Gyawali et al. (2005a) demonstrated the value of using such adaptive traits through participatory plant breeding (PPB) in Nepal. Other three LRs, viz. Thulo Gurdi, Ekle and Jetho Budho, have adaptive and other consumer-preferred traits (stability, aromatic and fine type) that make them competitive in their respective agroecosystems for continued cultivation and selection by farmers.

Hypothesis 2: Costs and returns differ little among LRs - less so than would be apparent between LRs and MVs.

Smale et al. (2000) indicated that production costs and total economic returns were most distinct between LRs and MVs rather than between LRs. The findings from the current study agree completely with their conclusion. However, LRs as a 'group' demonstrated huge variations in agronomic traits, production potential, production costs and economic returns. Table 4 also reveals that there are significant differences between LRs on economic returns. Farmers appreciate these differences and use information to trade-off for variety choice depending upon land types, fertility and other farmers' circumstances. Furthermore, Brown and Hodgkin (2007) suggest that landrace populations are highly heterogeneous and within population diversity can be greater than among populations. Farmers use diversity to manage adversity as it is very unpredictable. Therefore, it would be erroneous if they were treated as a homogeneous entity having similar features, and rejected a priori as inferior materials without proper evaluation.

Hypothesis 3: Farmers' differential management of varieties depends on the economic return generated by them.

The result suggests that farmers deploy varieties (LRs and MVs) to specific agroecosystems to match the performance of varieties to production system characteristics. Kieft (2001) reported that rice farmers in Timor have specific varieties for specific locations, and the decision on which variety to plant is very much based on the forecasts for the next rainy season. Farmers' decision on management of varieties is directed towards achieving the optimum result utilizing the existing farm resources. For example, in case of Mansara, though the landrace produced lower grain and straw yields, farmers still applied considerable amount of FYM and performed other management practices comparable with other better yielding varieties. Thus, differential treatment of varieties by farmers is the result of their understanding of the individual variety's requirement to produce in that agroecosystem. Farmers know that Mansara grown under low-fertility and low-water regime (marginal environment) and without adequate manure cannot produce grains. This illustrates that farmers' differential management is not based primarily on their economic returns, but rather on utility maximization from the given resources the farmers have. Thus, the decision is governed 
by their understanding of interaction between varieties and agroecosystems. Since the farmer already has rice land in a certain ecosystem, it is the matter of making the best use of it. For varieties within the agroecosystem, there was no statistically significant difference in the amount of manure applied and the management practices were more or less the same. Hence, the hypothesis stating a differential treatment of varieties based on the economic return they generate was found to be not true.

Hypothesis 4: Farmers' decision on the population size (measured by the area planted) of different varieties depends on their economic returns.

Sthapit et al. (2008) reported that rice varieties grown for food security and the market tend to be cultivated in large areas by many households. A study on sorghum varietal adoption and genetic diversity in Ethiopia suggested that yield stability was an important objective for farmers operating at subsistence level and it was associated with diversity within and between crop varieties (Mulatu and Belete, 2001). We also came to a similar conclusion. In the Nepalese context of subsistence-oriented farming system, attaining HH food security through production of grains takes precedence over economic analysis of production while making $\mathrm{HH}-\mathrm{level}$ decision on variety deployment, area allotment and management practices.

However, the hypothesis that area planted to a variety varies with economic return holds true for varieties within the same agroecosystem: Ekle with higher economic return occupied larger area than Thulo Gurdi in irrigated condition, while Mansuli with higher economic return was grown on a larger area when compared with Jetho Budho in marshy condition. But the statement was not true when the data were collated for all varieties and area compared between agroecosystems. This was primarily because varieties are specifically adapted to particular agroecosystems and therefore perform best in one agroecosystem and are competitive in that ecosystem. There is competition between varieties for area within an agroecosystem, but not necessarily between agroecosystems (Rana et al., 2007b). This finding has an important implication for setting breeding goals and targetting of specific environments and, consequently, selecting one of the parents as adapted to that environment for better plant breeding outcomes.

\section{Implications for on-farm conservation and crop improvement}

Much of the past research has demonstrated strong relationship between diversity in agroecosystems and diversity in crops and varieties, as farmers seek to optimize their management of environmental niches
(Brush et al., 1992; Zimmerer, 1996). Farmers maintain more diversity when they own and cultivate different land types and farming systems, choosing a broader portfolio of varieties to suit multiple classes of farmland and seasonal niches (Rana et al., 2007a). On-farm conservation is a process in which a wide range of genetic diversity co-evolves over time with natural and human intervention. LRs - the products of such processes are valued for global option value in the face of climate change and emerging new biotic and abiotic stresses in crop production (Bellon, 2008). Until recently, all LRs under all situations and under all environmental microniches were considered obsolete varieties, and concentrated efforts are made to replace these LRs before proper assessments are made to evaluate their comparative advantages. The low productivity of LRs is often considered to be the main reason for their disappearance from farmer's seed system. Consequently, Chaudhary et al. (2004) and Joshi and Bauer (2007) showed evidence that the number of LRs and the area cultivated under LRs are shrinking rapidly despite coexistence of both LR and MV at household and community levels. Most of the endangered LRs are adapted to rainfed or swampy micro-niches and difficult growing environments, and hence these LRs are important resources/assets for poor farmers. Rapid loss of these LRs consequently reduced the options for poor farmers in the face of climate change and other biotic stresses. Better understanding of agroecosystems and varietal adaptation by breeders is a must for appreciation of LRs, which could lead to their increased utilization in breeding programmes to generate materials 'tuned to the agroecosystems' and thereby support on-farm conservation as it allows continued cultivation in farmers' fields.

The study suggests that a systematic evaluation of LRs can benefit a community in three ways: (1) enhancing access of information and seed of locally adapted germplasm in a similar environment where plant breeding cannot reach; (2) exploiting market potential of unique traits found in LRs; and (3) improving the competitiveness of LRs by eliminating undesirable traits through participatory crop improvement. There is a need to ensure not only better access to both locally adapted local LRs and MVs, but also use of useful traits in decentralized and participatory plant breeding for low-input agriculture (Dawson et al., 2007; McGuire, 2007; Sthapit and Rao, 2007). Recognition of this by breeding programmes could lead to a new direction for utilization of local crop diversity for such environments. Ekle landrace, for example, is cultivated in the largest rice area (18.4\%) in the communities compared with other studied cultivars (4.1-13.8\%). Drawing information from diversity assessment of rice LRs, seeds of common LRs such as Thulo Gurdi and Ekle can be tested in other similar target production 
environments through participatory variety selection as Ekle landrace has similar economic return to Mansuli (MV). In the mid-hill (800-100 masl) irrigated agroecosystems, this variety is reported to produce stable grain and straw yields over the years and no MVs recommended for this domain were able to replace it due to its capacity to tolerate biotic and abiotic stresses resulting in high yield stability and an intermediate economic return under a low-input farming system. Of 57 community rice diversity documented in this village, many endangered (grown by few households in small areas) LRs can be options for similar agroecosystems in other parts of the country and region. These kinds of simple community-based genetic resource management can provide immediate benefits to poor farmers. The benefits from a landrace such as Jetho Budho can be captured by premium prices in markets as consumers are willing to pay high price for its aroma and cooking qualities. The intraspecific diversity within Jetho Budho population has been exploited through participatory landrace enhancement to offer better quality Jetho Budho in the market (Gyawali et al., 2005b). This strategy can ensure on-farm conservation of this traditional variety as long as consumers are willing to pay high prices for these types of rice.

PPB can be one of the strategies for on-farm conservation of LRs (Sthapit et al., 2002) by eliminating undesirable traits from LRs and/or incorporating good traits from locally adapted LRs into modern cultivars. Locally adapted LRs can be used as one of the parents whose useful traits can be incorporated with an exotic parent to eliminate negative traits found in farmers' varieties. Successful case studies have been demonstrated by Sthapit et al. (1996) and Witcombe et al. (2005).

There is no economic sense to grow Mansara landrace in over $7 \%$ rice area of the Begnas village (Table 4). Farmers appreciate the value of Mansara variety for its ability to grow and produce some rice where other MVs and LRs cannot produce. Such LRs are important natural assets for those poor farmers who have to live on genetic resources that thrive on poor land. However, productivity and eating quality of this landrace are very poor. In order to maintain competitiveness of Mansara landrace, the breeding goal was set to incorporate the better eating quality and yield potential of the most popular cultivar Khumal-4 in the mid-hills into the locally adapted landrace Mansara (poor in eating quality; Gyawali et al., 2005a). Mansara that has pro-poor trait (ability to grow in low-fertility and low-moisture regimes) was chosen as a parent for its adaptive traits to the marginal rice environment (Sthapit et al., 2002).

\section{Conclusion}

On-farm crop diversity provides means for adapting crops to meet rapidly changing climatic conditions, with their diverse effects on the magnitude and frequency of both biotic and abiotic stresses. In order to conserve LRs on-farm, it would be imperative to make them more competitive through agronomic research and by utilizing LRs in breeding programmes to improve certain negative traits. Efforts have to be made by research and development professionals to increase farmers' participation in on-farm assessment and selection of materials to ensure appropriate materials reach farmers. We found that LRs are very diverse on agronomic and economic traits and farmers deploy these LRs to agroecosystems based on their understanding of characteristics of varieties and target production environments (agroecosystems) and the interaction between them. A few LRs can compete with MVs under niche-specific marginal environments and such specific LRs can be valuable assets under similar conditions in other parts of the country that are without much crop improvement efforts. Consolidating farmers' role in plant breeding will provide certain rights to the farmers to save, use, sow, re-sow, exchange, share or sell their farm produce, support on-farm conservation process and prepare communities to cope with changing situations. This will not only increase chances of maintenance of LRs on-farm, but will also contribute positively to $\mathrm{HH}$ food security and maintenance of useful crop diversity.

\section{Acknowledgements}

The authors would like to thank farmers of Begnas and Kachorwa villages, and Dr Devra Jarvis, global project coordinator from Bioversity, and anonymous reviewers who provided valuable information and advice. This work is an output of a PhD study (Rana, 2004) from the Bioversity's Global Project, 'Strengthening Scientific Basis of In-situ Conservation of Agricultural Biodiversity Onfarm: Nepal Country Component' funded by the Netherlands Ministry of Foreign Affairs Development Cooperation DGIS (Activity number: ww104801), IDRC and SDC.

\section{References}

Atlin GN, Cooper M and Bjornstad A (2001) A comparison of formal and participatory breeding approaches using selection theory. Euphytica 122: 463-475.

Bajracharya J (2003) Genetic diversity study in landraces of rice by agro-morphological characters and micro satellite DNA markers PhD Thesis, University of Wales, UK.

Bellon MR (2008) Do we need crop landraces for the future? Realizing the global option value of in situ conservation. In: Kontoleon A, Pascual U and Smale M (eds) Agrobiodiversity and Economic Development. USA: Routledge.

Brown AHD and Hodgkin T (2007) Measuring, managing and maintaining crop genetic diversity on farm. In: Jarvis D, 
Padoch C and Cooper D (eds) Managing Biodiversity in Agricultural Ecosystems. New York: Colombian University Press, pp. 13-33.

Brush SB (1995) In situ conservation of landraces in centres of crop diversity. Crop Science 35: 346-354.

Brush SB and Meng E (1998) Farmers' valuation and conservation of crop genetic resources. Genetic Resources and Crop Evolution 45: 139-150.

Brush SB, Taylor JE and Bellon MR (1992) Technology adoption and biological diversity in Andean potato agriculture. Journal of Development Economics 2: 365-387.

Byerlee D (1996) Modern varieties, productivity, and sustainability: recent experiences and emerging challenges. World Development 24: 697-718.

Carpenter D (2005) The in situ conservation of rice plant genetic diversity: a case study from a Philippine Barangay. Agriculture and Human Values 22: 421-434.

Ceccarelli S (2000) Wide adaptation: how wide? Euphytica(3): $197-205$.

Chaudhary P, Gauchan D, Rana RB, Sthapit BR and Jarvis DI (2004) Potential loss of rice landraces from a Terai community in Nepal: a case study from Kachorwa, Bara. Plant Genetic Resource Newsletter 137: 14-22.

Cleveland DA, Soleri D and Smith SE (2000) A biological framework for understanding farmers' plant breeding. Economic Botany 54(3): 377-394.

Dawson JC, Murphy KM and Jones SS (2007) Decentralized selection and participatory approaches in plant breeding for low input systems. Euphytica doi:10.1007/s10681-007-9533-0.

Frankel OH, Brown AHD and Burdon JJ (1995) The Conservation of Plant Biodiversity. Cambridge: Cambridge University Press.

Gorrez FD Jr and Chaurasia PCP (1997) Rice Production Guidelines: Non-Cash Input Technologies Hill Food Production Project, Nepal: DoA/MoA/HMG

Gyawali S, Joshi KD, Tiwari R, Shrestha P, Joshi B, Chaudhary B, Mudwari A, Baniya B, Subedi A, Bhandari B, Upadhyay MP, Tripathi M, Adhikari N, Shrestha K and Sthapit BR (2005a) Participatory plant breeding: a strategy of in situ conservation of rice landraces. In: Sthapit BR, Upadhyay MP, Shrestha PK and Jarvis DI (eds) Proceeding of On-farm Conservation of Agricultural Biodiversity in Nepal. Vol. II. Managing Diversity and Promoting Its Benefits. Kathmandu: NARC, LI-BIRD and IPGRI, pp. 202-212.

Gyawali S, Sthapit BR, Bhandari B, Gauchan D, Joshi B, Paudel IP, Subedi SR, Upadhyay MP and Shrestha PK (2005b) Jethobudho enhancement I: a participatory method for on-farm management of agrobiodiversity. In: Sthapit BR, Upadhyay MP, Shrestha PK and Jarvis DI (eds) Proceeding of On-farm Conservation of Agricultural Biodiversity in Nepal. Vol. II. Managing Diversity and Promoting Its Benefits. Kathmandu: NARC, LI-BIRD and IPGRI, pp. 161-171.

Harlan JR (1975) Our vanishing genetic resources. Science 188: 618-621.

Hobbs PR, Harrington LW, Adhikari C, Giri GS, Upadhyay SR and Adhikari B (1996) Wheat and Rice in the Nepal Terai: Farm Resources and Production Practices in Rupandebi District, Nepal. Nepal: NARC and CIMMYT.

Hodgkin T, Rao VR and Riley K (1993) Current issues in conserving crop landraces in situ Paper Presented at the On-farm Conservation Workshop, Indonesia, 6-8 December.

Horneburg B and Becker HC (2008) Crop adaptation in on-farm management by natural and conscious selection: a case study with lentil. Crop Science 48: 203-212.
Jarvis D and Hodgkin T (2000) Farmer decision making and genetic diversity: linking multi-disciplinary research to implementation on-farm. In: Brush S (ed.) Genes in the Field: On-farm Conservation of Crop Diversity. Boca Raton, FL: IPGRI, IDRC, and Lewis Publication, pp. 261-278.

Jarvis D, Mayer L, Klemick H, Guarino L, Smale M, Brown AHD, Sadiki M, Sthapit BR and Hodgkin TA (2000) Training Guide for In Situ Conservation On-farm. Rome, Italy: IPGRI.

Jarvis DI, Brown AHD, Cuong PH, Collado-Panduro L, Latourniere-Moreno L, Gyawali S, Tanto T, Sawadogo M, Mar I, Sadiki M, Hue NTN, Arias-Reyes L, Balma D, Bajracharya J, Castillo F, Rijal D, Belqadi L, Rana R, Saidi S, Ouedraogo J, Zangre R, de Santis P, Fadda C and Hodgkin T (2008) A global perspective of the richness and evenness of traditional crop genetic diversity maintained by farming communities.: 1-6 Proceedings of the National Academy of Sciences PNAS (USA) www.pnas.org/cgi/doi/10.1073/ pnas.0800607105.

Joshi GR and Bauer S (2007) Cultivation and the loss of rice landraces in the Terai region of Nepal. Plant Genetic Resources: Characterization and Utilization 5(1): 1-6 doi:10.1017/S1479262107203788.

Khush GS (1984) Terminology for Rice-growing Environments. Manila, Philippines: IRRI.

Kieft J (2001) Indigenous variety development in food crops strategies on Timor: their relevance for in situ biodiversity conservation and food security. Indigenous Knowledge and Development Monitor, July 2001 http://www.nuffic.nl/ ciran/ikdm/9-2/kieft.html accessed date:04/09/2003.

McGuire SJ (2007) Securing access to seed: social relations and sorghum seed exchange in Eastern Ethiopia. Human Ecology 36(2): 217-229.

Mulatu E and Belete K (2001) Participatory variety selection in lowland sorghum in eastern Ethiopia: impact on adoption and genetic diversity. Experimental Agriculture 37: 211-229.

Paudel D, Chaudhary P, Chowi KR and Ghimire H 2003 Case studies of seed production and marketing through farmers groups in Nepal. Discussion Paper No. 4. Bangor CAZS, UK and LI-BIRD, Pokhara, Nepal.

Perales RH, Brush SB and Qualset CO (1998) Agronomic and economic competitiveness of maize landraces and in situ conservation in Mexico. In: Smale M (ed.) Farmers, Gene Bank and Crop Breeding: Economic Analysis of Diversity in Wheat, Maize and Rice. USA: CIMMYT/Kluwer Academic Publisher.

Rana RB (2004) Influence of socio-economic and cultural factors on agro-biodiversity conservation onfarm in Nepal. PhD thesis, IRDD, The University of Reading, UK.

Rana RB and Sthapit BR (2006) Intensive data plot for understanding farmer's decisions on management of agricultural biodiversity on farm. In: Sthapit BR, Shrestha PK and Upadhyay MP (eds) Good Practices: On-farm Management of Agricultural Biodiversity in Nepal. Nepal: NARC, LI-BIRD, IPGRI and IDRC.

Rana RB, Garforth C, Jarvis D and Sthapit BR (2007a) Influence of socio-economic and cultural factors in rice varietal diversity management on-farm in Nepal. Agriculture and Human Values 24(4): 461-472.

Rana RB, Garforth CJ, Sthapit BR, Subedi A and Jarvis DI (2007b) On-farm management of rice genetic diversity: understanding farmers' knowledge on rice ecosystems and varietal deployment. Plant Genetic Resources Newsletter 152: 58-64.

Sadiki M, Belqadi L, Mahdi M and Jarvis D (2001) Identifying units of diversity management by comparing traits used 
by farmers to name and distinguish faba bean (Vicia faba L.) cultivars with measurements of genetic distinctiveness in Morocco Proceedings of the Legumed Symposium, Grain Legumes in the Mediterranean Agriculture, 25-27 October, Rabat, Morocco. Paris: AEP

Sadiki M, Jarvis D, Rijal D, Bajracharya J, Hue N, Camacho-Villa T, Burgos-May L, Sawadogo M, Balma D, Lope D, Arias L, Mar I, Karamura K, Williams D, Chavez-Servia J, Sthapit B and Rao VR (2007) Variety names: an entry point to crop genetic diversity and distribution in agroecosystems? In: Jarvis D, Padoch C and Cooper D (eds) Managing Biodiversity in Agricultural Ecosystems. USA: Colombia University Press, pp. $12-34$.

Science Council Secretariat Consultative Group on International Agricultural Research (CGIAR) System Research Priorities 2005-2015, Science Council Secretariat2005

Smale M, Bellon M and Aguirre A (2000) Maize diversity, variety attributes, and farmers' choices in southern Guanajuto, Mexico. Economic Development and Culture Change 50: 201-225.

Smale M, Bellon M, Jarvis D and Sthapit B (2004) Economic concepts for designing policies to conserve crop genetic resources on-farms. Genetic Resources and Crop Evolution 51: $121-135$.

Sthapit BR and Rao VR (2007) Grassroots breeding: a way to optimise the use of local crop diversity for well-being of people Paper presented at the Tropentag Conference, 9-11 October, Witzenhausen, Germany.

Sthapit BR, Joshi KD and Witcombe JR (1996) Farmer participatory crop improvement. III. Participatory plant breeding, a case study for rice in Nepal. Experimental Agriculture 32: 479-496.

Sthapit BR, Bajracharya J, Subedi A, Joshi KD, Rana RB, Khatiwada SP, Gyawali S, Chaudhary P, Tiwari T, Rijal D, Shrestha KP, Baniya BK, Mudwari A, Upadhyay MP, Gauchan D and Jarvis D (2002) Enhancing on-farm conservation of traditional rice varieties in situ through PPB in three contrasting sites from Nepal. In: Witcombe JR and Parr LB (eds) Breeding Rainfed Rice for Drought-Prone Environments: Integrating Conventional and Participatory Plant Breeding in South and Southeast Asia. Proceedings of a DFID Plant Sciences Research Program/IRRI Conference, Los Banos, 12-15 March. Philippines: IRRI.

Sthapit BR, Eyzaguirre PE, Jarvis DI and Rana RB (2008) The value of genetic diversity to resource - poor farmers in Nepal and Vietnam. International Journal of Agricultural Sustainability 6(2): 148-166 doi:10.3763.ijas.2007.0291.

Tripp R, Louwaars N, Joost van der Burg W, Virk DS and Witcombe JR (1997) Alternatives for seed regulatory reform: an analysis of variety testing, variety regulation and seed quality control. Agricultural Administration (Research and Extension) Network Paper No. 69. London: ODI.

Virk DS and Witcombe JR (2006) Trade off between on-farm varietal diversity and highly client-oriented breeding: a case study of upland rice in India. Genetic Resources and Crop Evolution 54: 823-835.

Witcombe JR, Joshi A, Joshi KD and Sthapit BR (1996) Farmer participatory crop improvement. I. Varietal selection and breeding methods and their impact on biodiversity. Experimental Agriculture 32: 445-460.

Witcombe JR, Joshi KD, Gyawali S, Musa AM, Johansen C, Virk DS and Sthapit BR (2005) Participatory plant breeding is better described as highly client-oriented plant breeding. I. Four indicators of client-orientation in plant breeding. Experimental Agriculture 41: 299-319.

Wood D and Lenne JM (1997) The conservation of agrobiodiversity on-farm: questioning the emerging paradigm. Biodiversity and Conservation 6: 109-129.

Zeven AC (1998) Landraces: a review of definitions and classifications. Euphytica 104: 127-139.

Zimmerer KS (1996) Changing Fortunes: Biodiversity and Peasant livelihood in the Peruvian Andes. Berkeley: University of California Press. 